\title{
EFEK MEDIA DEMONSTRASI KIMIA YANG DIMODIFIKASI TERHADAP PEMAHAMAN MAHASISWA PADA KONSEP ELEKTROKIMIA
}

\author{
Muti’ah, Jakcson Siahaan, Sukib \\ ${ }^{1}$ Program Studi. Pendidikan Kimia, Jurusan PMIPA, FKIP Unram, Mataram, Indonesia \\ Email: muti’ah@unram.ac.id
}

\begin{abstract}
Abstrak. Tujuan penelitian ini untuk menyelidiki pengaruh penerapan media demonstrasi kimia yang dimodifikasi terhadap pemahaman mahasiswa pada konsep sel elektrokimia. Sampel yang digunakan adalah mahasiswa Program Studi Pendidikan Kimia, FKIP Universitas Matram, Indonesia. Penelitian merupakan penelitian kuasi eksperimen yang menggunakan kelas kontrol (metode konvensional) dan kelas eksperimen (media demonstrasi kimia yang dimodifikasi). Hasil penelitian menunjukan bahwa setelah dilakukan pembelajaran hasil tes akhir/post tes menunjukan bahwa persentase mahasiswa yang menguasai konsep dengn benar sebesar 36\% untuk kelas kontrol dan kelas eksperimen sebanyak 56\%. Perbaikan miskonsepsi tertinggi terdapat pada subtopik sebagai berikut: reaksi pada elektroda (9\%), fungsi jembatan garam (9\%), aliran muatan listrik pada rangkaian luar (6\%), dan rangkaian tertutup dan terbuka (4\%). Hasil uji statistik anacova menunjukan bahwa ada pengaruh signifikan penggunaan media demonstrasi kimia yang dimodifikasi terhadap perbaikan miskonsepsi mahasiswa pada topik elektrokimia. Dari penelitian ini dapat disimpulkan bahwa media demonstrasi kimia yang dimodifikasi mampu memperbaiki miskonsepsi karena sesuai dengan prinsip model mental dan representasi dari ilmu kimia
\end{abstract}

\section{Kata kunci: demonstrasi kimia dimodifikasi, miskonsepsi, sel elektrokimia}

\begin{abstract}
The aim of this study was to investigate the effect of the application of chemical demonstration on the students' understanding of the concept of an electrochemical cell. The chemistry students of Faculty of Teacher Training and Science Education, Mataram University, Indonesia was taken as samples. The study was quasiexperimental research in which the control classes was taught using conventional methods and the experimented classes was taught by incorporating chemistry demonstration experiment. The results showed that the percentage of students who mastered the concept correctly was 36\% and 56\% for the control group and the experimental class, respectively. Repair misconception shows that the highest values found in the subtopics as follows: reaction on the electrode $(9 \%)$, the function of the salt bridge $(9 \%)$, the flow of electric charge on the circuit outside $(6 \%)$, and the flow of electricity on a series of closed and open (4\%). Anacova statistical test results showed that there was a significant effect of the use of chemically modified media demonstration on reducing student misconceptions. It can be concluded that the demonstration of the modified chemical capable of reducing misconceptions students on the topic of electrochemistry.
\end{abstract}

Keywords: chemistry demonstration, misconceptions, electrochemical

\section{PENDAHULUAN}

Penguasaan konsep kimia dasar bagi mahasiswa tingkat pertama sangat penting, karena menjadi dasar pemahaman kimia kimia lanjut [1]. Topik-topik esensial dalam matakuliah kimia dasar terutama adalah termokimia, kesetimbangan kimia, sel elektrokimia, stiokhiometri, struktur atom dan molekul, serta laju reaksi $[1,2]$. Namun demikian dari hasil refleksi tim pengajar selama melakukan pembelajaran di kelas menunjukkan bahwa " perhatian dan motivasi sangat rendah, dan banyak terjadi miskonsepsi siswa, sehingga hasil belajar rendah".

Secara lebih jelas Treagust [3] mengklasifikasikan fenomena/konsep kimia pada tiga tingkat representasi; yaitu tingkat makroskopik, submikroskopik, dan simbolik, dimana ketiganya saling memiliki keterkaitan. Kemudian dijelaskan bahwa tingkat makroskopik merupakan fenomena nyata yang dapat secara langsung diamati dan dapat dirasakan oleh panca indera, tingkat submikroskopik merupakan fenomena nyata, tetapi memerlukan teori untuk menjelaskan pada tingkat molekuler dan atomik. Selanjutnya tingkat simbolik merupakan representasi dari fenomena nyata yang dinyatakan dalam bentuk gambar, simbol atau rumus kimia, persamaan reaksi, grafik, maupun mekanisme reaksi.

Kozma dan Russell [4] serta Chandrasegaran [5] menyatakan bahwa representasi submikroskopik merupakan faktor kunci. Hal tersebut memberi arti bahwa ketidak-mampuan dalam merepresentasikan aspek submikroskopik akan menghambat kemampuan yang terkait dengan fenomena tingkat makroskopik dan simbolik. Oleh karena itu Treagust [3] menyarankan untuk menggunakan strategi dan kondisi pembelajaran kimia dalam bentuk representasi makroskopik, mikroskopik, dan simbolik secara simultan/bersamaan.

Pembelajaran yang dapat merepresentasikan ketiga tingkatan tersebut secara simultan telah diterapkan oleh Muti'ah [6,7], yaitu metode demonstrasi kimia yang dimodifikasi pada perkuliahan Chemical 
Separation. Metode pembelajaran tersebut dapat memperbaiki miskonsepsi, karena sejalan konstruksi model mental siswa yang diungkap oleh Chittleborough [8]. Media demonstrasi kimia terkait dengan konstruksi pada tingkat makroskopis, sedangkan media power point/animasi terkait dengan konstruksi di tingkat submikroskopis dan simbolik $[9,10]$.

Hasil penelitian Muti'ah dan Burhanuddin [11] menunjukkan banyaknya miskonsepsi mahasiswa dalam memahami kesetimbangan kimia. Muti'ah dan Sukib [12] juga telah mengidentifikasi banyaknya miskonsepsi mahasiswa dalam memahami konsep elektrokimia. Dalam upaya memperbaiki miskonsepsi mahasiswa pada topik sel elektrokimia dan kesetimbangan kimia, Muti'ah [13] telah mengembangkan media demonstri kimia yang dimodifikasi memalui penelitian tindakan kelas.

Dari hasil penelitian tindakan kelas tersebut menunjukkan bahwa penerapan metode demonstrasi kimia yang dimodifikasi mampu meningkatan perhatian, motivasi dan mengatasi miskonsepsi mahasiswa. Namun demikian kesimpulan tersebut diperoleh dari hasil penlitian tindakan kelas yang bersifat deskriptif. Untuk memperoleh kesimpulan yang lebih umum dan lebih meyakinkan maka perlu dibuktikan melalui penelitian eksperiumen.

Tujuan umum dari penelitian ini adalah terwujudnya pembelajaran kimia dasar yang berkualitas melalui penggunaan demonstrasi kimia yang dimodifikasi. Adapun tujuan khusus untuk mengetahui ada/tidaknya pengaruh penggunaan media demonstrasi kimia yang dimodifikasi terhadap hasil belajar kimia dasar yang dikontrol oleh pre-tes

\section{METODE PENELITIAN}

Penelitian ini dilaksanakan di Program Studi Pendidikan Kimia, FKIP Unram. Sebagai populasi adalah mahasiswa tahun pertama Jurusan PMIPA FKIP Unram yang mengikuti matakuliah kimia dasar. Sampel yang digunakan adalah mahasiswa Progdi. Pend. Kimia. Teknik pengambilan sampel secara purposif dengan pertimbangan memiliki karakteristik hampir sama. Penelitian ini dirancang menggunakan quasi eksperimen/eksperimen semu, karena sampel diambil tidak secara random, menggunakan kelas kontrol, serta pre-tes dan post-tes [14].

Tahap awal penelitian ini adalah pembuatan perangkat pembelajaran dan instrumen. Sebanyak 4 jenis media telah dibuat, yaitu topik sel elektrokimia (reaksi redoks dan sel Galvanik) dan konsep kesetimbangan kimia (hukum kesetimbangan dan prinsip Le Chatelier). Instrumen tes yang digunakan berupa tes tertulis yang mengacu pada peneliti terdahulu [15].

Pelaksanaan pembelajaran dilakukan dalam 2 kelas, yaitu kelas kontrol menggunakan metode konvensional dan kelas eksperimen menggunakan media demonstrasi kimia yang dimodifikasi. Data yang diperoleh berupa data kuantitatif dan kualitatif. Data kuantitatif yang berupa nilai pre-tes dan post-tes dianalisis menggunkan statistik Anacova.

\section{HASIL DAN PEMBAHASAN}

Permasalahan yang diungkap dalam penelitian ini adalah "Apakah ada pengaruh penggunaan media demonstrasi kimia yang dimodifikasi terhadap hasil belajar mahasiswa. Oleh karena itu data hasil penelitian dinalisis secara statistik anacova sebagaimana tercantum dalam tabel 1. Berdasarkan hasil analisis statistik menunjukan bahwa $\mathrm{F}_{\text {hitung }}$ diperoleh 3,47 sedangkan $\mathrm{F}$ tabel pada $\alpha 5 \%$ diperoleh 3,37 sehingga F-hitung > Ftabel. Dari perhitungan ini menunjukan bahwa setelah dikendalikan oleh kovariabel pre-tes ada pengaruh signifikan hasil belajar siswa pada topik sel elektrokimia yang mengguna-kan media demonstrasi kimia yang dimodifikasi.

Secara kuantitatif kesimpulan tersebut di atas dapat didukung oleh data rata-rata nilai hasil belajar mahasiswa sebagaimana tercantum dalam gambar 1 . Dari gambar 1 menunjukan bahwa selisih nilai post tes dan pre tes menunjukan perbedaan antara kelas kontrol dan eksperimen, yaitu masing-masing sebesar 1,9 dan 2,8. Oleh karena itu secara kuantitatif kelas eksperimen lebih baik dari pada kelas kontrol. Untuk mengetahui persentase mahasiswa yang menguasai konsep sel elektrokimia dengan benar dapat dilihat pada tabel gambar 2. Dari hasil pre-tes baik kelas kontrol maupun eksperimen menunjukan persentase yang cukup, yaitu kelas kontrol sekitar 30\% sedangkan kelas eksperimen $38 \%$. Setelah dilakukan pembelajaran hasil tes akhir/post tes menunjukan bahwa persentase mahasiswa yang menguasai konsep dengn benar sebesar 36\% untuk kelas kontrol dan kelas eksperimen sebanyak $56 \%$. Hal ini menunjukan bahwa persentase terbesar mahasiswa yang menguasai konsep dengan benar terdapat di kelas eksperimen dengan beda sebesar $12 \%$.

Tabel.1. Ringkasan Statistik Anacova Hasil Belajar Sel Elektrokimia

\begin{tabular}{|c|c|c|c|c|c|}
\hline Sumber Varian SV & $\mathrm{JK}$ & $\mathrm{dB}$ & RJK & $F_{\text {hitung }}$ & Ft $5 \%$ \\
\hline Antar A & 25,13 & 2 & 12,56 & 3,47 & 3,37 \\
\hline Dalam & 206,44 & 57 & 3,62 & & \\
\hline Total (residu) & 231,57 & 58 & & & \\
\hline
\end{tabular}




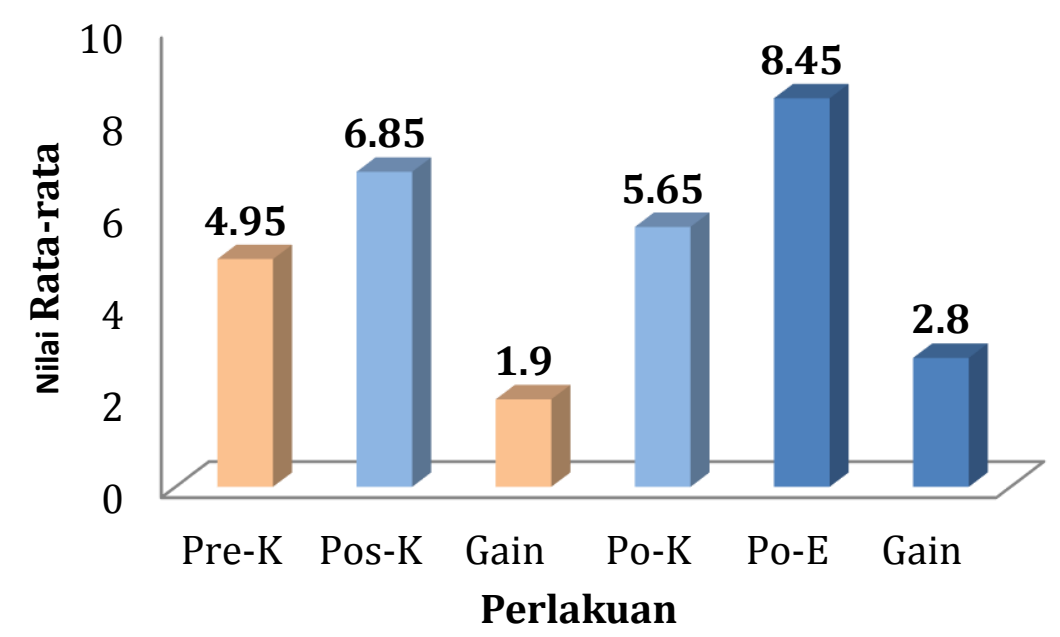

Gambar 1. Nilai rata-rata pre dan pos tes kelas kontrol dan eksperimen

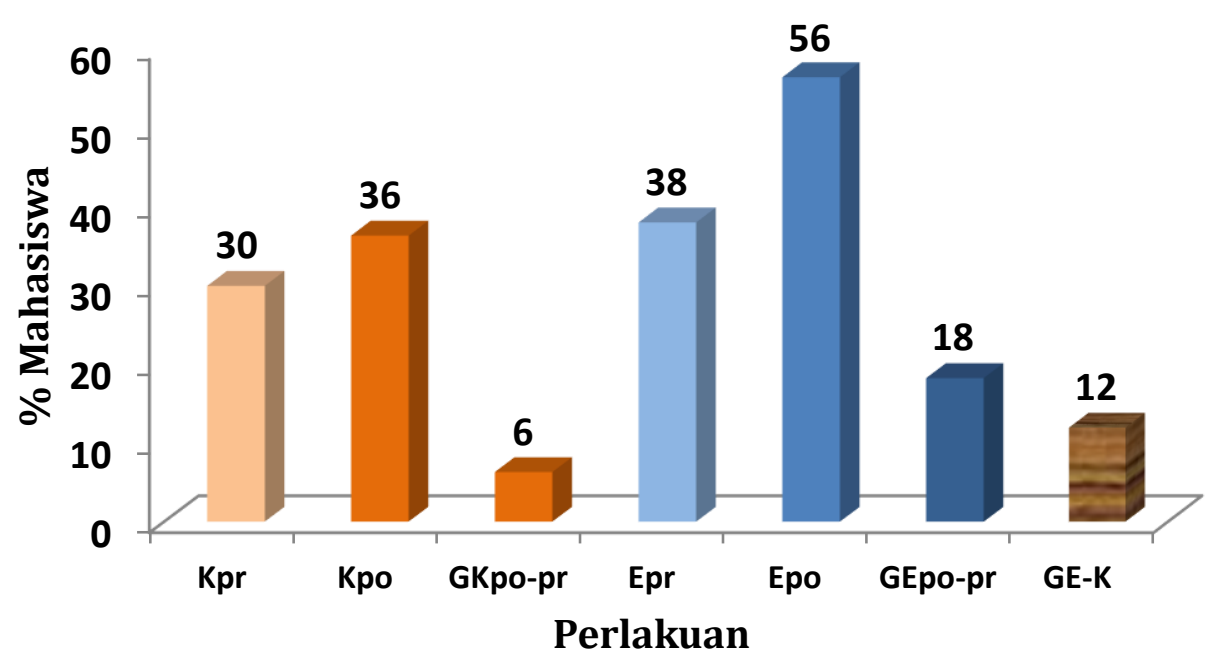

Gambar 2. Persentase mahasiswa yang menguasai konsep elektrokimia

Data Tabel 2 menunjukan selisih nilai \% mahasiswa yang menguasai konsep tertentu pada kelas kontrol dan eksperimen.

Tabel 2. Persentase peningkatan persentase mahasiswa setelah pembelajaran

\begin{tabular}{clccc}
\hline No & \multicolumn{1}{c}{ Konsep yang diteliti } & Kon. & Eks. & Gain \\
\hline 1 & Identifikasi reaksi redoks & 8 & 11 & 3 \\
2 & Transfer elektron dalam reaksi redoks & $\mathbf{2}$ & $\mathbf{3}$ & $\mathbf{1}$ \\
3 & Susunan rangkaian sel volta & $\mathbf{2}$ & $\mathbf{0}$ & $\mathbf{- 2}$ \\
4 & Identifikasi jenis elektroda & $\mathbf{1}$ & $\mathbf{3}$ & $\mathbf{2}$ \\
5 & Reaksi yang terjadi pada elektroda & -3 & 6 & 9 \\
6 & Aliran muatan listrik dalam rangkaian luar & -1 & 5 & 6 \\
7 & Aliran muatan listrik pada rangkaian dalam & 7 & 5 & -2 \\
8 & Fungsi jembatan garam & 2 & 11 & 9 \\
9 & Konduktor dan hantaran elektrolit & 2 & 1 & -1 \\
10 & Rangkaian tertutup dan terbuka & 4 & 8 & 4 \\
\hline
\end{tabular}




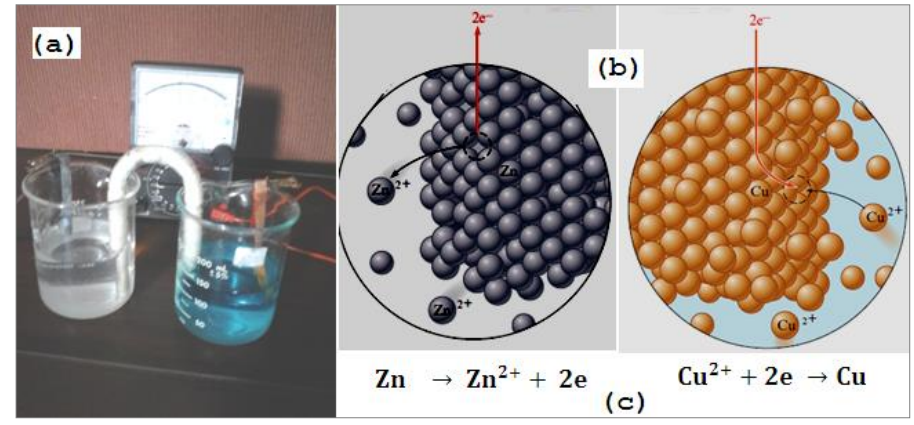

Gambar 3. Representasi 3 level pada konsep reaksi pada elektroda
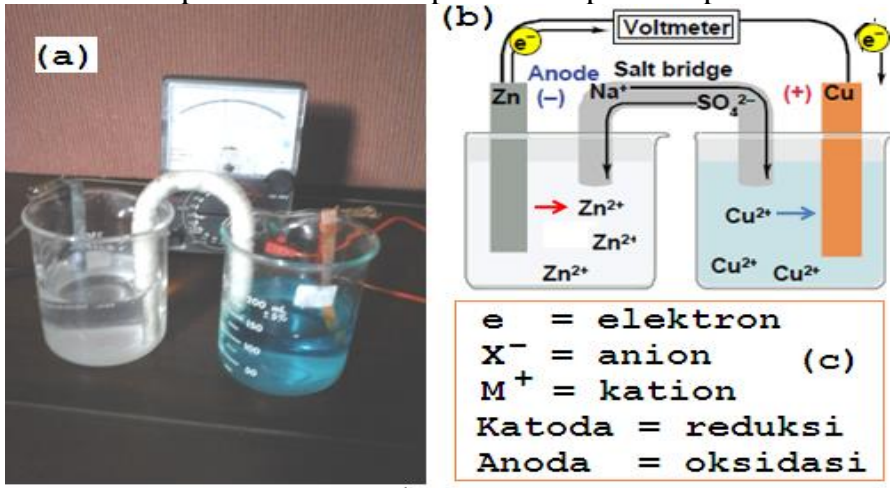

Gambar 4. Representasi 3 level pada konsep aliran muatan listrik pada elektrolit dan jembatan garam

larutan

Dari data pada tabel 2 menunjukan bahwa perbedaan persentase mahasiswa yang menguasai konsep dengan benar dari hasil pembelajaran dengan metode konvensional dan media demonstrasi kimia yang dimodifikasi cukup bervariasi. Urutan perbedaan dari tertinggi hingga terendah adalah sebagai berikut:

(1) reaksi pada elektroda $(9 \%)$,

(2) fungsi jembatan garam (9\%),

(3) aliran muatan listrik pada rangkaian luar (6\%),

(4) rangkaian tertutup dan terbuka (4\%),

(5) identifikasi reaksi redoks (3\%),

(6) identifikasi jenis elektroda (2\%),

(7) transfer elektron dalam reaksi redoks (1\%),

(8) konduktor dan hantaran elektrolit $(-1 \%)$,

(9) susunan sel volta $(-2 \%)$,

(10) aliran muatan listrik pada rangkaian dalam (-2).

Berdasarkan hal tersebut menunjukan bahwa media demonstrasi kimia yang dimodifikasi dapat meningkatkan pemahaman konsep mahasiswa terutama pada topik: reaksi pada elektroda, mekanisme aliran listrik dalam larutan elektrolit dan jembatan garam, aliran muatan listrik dalam rangkaian luar, serta rangkaian tertutup dan terbuka. Hal tersebut dapat dijelaskan berdasarkan model mental siswa sebagaimana diungkap oleh Treagust [3] bahwa ilmu kimia mengkaji fenomena nyata (makroskopis), tetapi melibatkan konsep-konsep yang bersifat abstrak (submikroskopis).

Oleh sebab itu ketika menjelaskan konsep kimia seorang pengajar seharusnya mampu menjelaskan fenomena kimia pada tiga tingkat representasi secara simultan; yaitu tingkat makroskopik, submikroskopik, dan simbolik. Media demonstrasi kimia yang dimodifikasi mampu memadukan antara level makroskopis (media demonstrasi kimia) dengan level simbolik dan submiroskopis (media power point yang memuat gambar, rumus kimia, persamaan reaksi, grafik, dan konsep-konsep terkait). Oleh karena itu pembelajaran menggunakan media demonstrasi kimia yang dimodifikasi dapat mempermudah pembentukan model mental siswa pada tingkat makroskopis, submikroskopis dan simbolik.

Salah satu media demonstrasi kimia yang dimodifikasi dalam menjelaskan reaksi-reaksi pada elektroda dapat dilihat pada gambar 3. Gambar 3(a) merepresentasikan elektroda secara makroskopis/nyata. Oleh sebab itu mahasiswa dapat mengamati secara langsung dan mencobanya, sehingga interaksinya dengan obyek yang dipelajari lebih kuat dalam mengkonstruksi konsep tersebut. Hal ini sesuai dengan pendapat Piaget yang menekankan bahwa pembentukan/konstruksi pengetahuan seorang anak adalah hasil dari pengalaman dan interaksinya dengan objek yang dihadapinya yang dilakukan oleh aktivitas individu [16].

Gambar 3(b) menunjukan penjelasan konsep reaksi elektroda pada level submikroskopis. Level sub mikroskopis merupakan level yang membutuhkan pemikiran ditingkat molekuler atau atomik. Oleh karena itu konsep tersebut sering disebut sebagai konsep abstrak dimana oleh beberapa peneliti diakui sebagai alasan mengapa ilmu kimia sulit dipahami siswa [17]. Adanya penjelasan yang menggambarkan level sub mikroskopis tersebut dapat membantu siswa dalam memahami konsep abstrak menjadi nyata. 
Gambar 3(c) menunjukan penjelasan konsep reaksi elektroda pada level simbolik. Level simbolik merupakan hal yang penting bagi siswa karena level tersebut mampu menyederhanakan konsep kimia yang cukup rumit. Dalam hal ini penjelasan reaksi-reaksi kimia pada elektroda cukup dengan menuliskan persamaan reaksi. Pada umumnya siswa yang belajar ilmu kimia hanya menguasai konsep dalam bentuk simbolik, sehingga mereka tidak memahami bagaimana proses sebenarnya yang terjadi pada suatu materi.

Konsep berikutnya yang mampu dipahami dengan baik oleh mahasiswa setelah pembelajaran adalah fungsi jembatan garam. Pernyataan siswa pada konsep tersebut bervariasi, yaitu:

(1) Selama sel galvanik beroperasi, maka anion dari jembatan garam masuk ke larutan sekitar katoda dan kation dari jembatan garam masuk ke anoda

(2) Selama sel galvanik beroperasi, maka ion $\mathrm{Zn}^{2+}$ dalam $1 / 2$ sel $\mathrm{Zn}$ dengan jumlah banyak masuk ke jembatan garam

(3) Selama sel galvanik beroperasi, maka anion dari jembatan garam masuk ke larutan sekitar anoda dan kation dari jembatan garam masuk ke katoda

Sebagian besar siswa menjawab salah pada kelas kontrol. Beberapa siswa juga belum mengetahui secara nyata mengenai, jembatan garam, larutan elektrolit dan susunannya, sehingga siswa hanya menghafal dari beberapa literatur. Berbeda dengan siswa kelas eksperimen, dalam pembelajarannya telah dikenalkan secara nyata tentang susunan jembatan garam-larutan elektrolit dan elektroda. Disamping itu kelas eksperimen juga diperkenalkan secara sub mikroskopis bagaimana pergerakan arus listrik (gambar 4)

Gambar 4(a) menunjukan representasi tentang larutan elektrolit-elektroda dan jembatan garam yang sebenarnya. Dengan adanya media nyata, maka mahasiswa dapat mengamati secara langsung dan mencobanya sehingga terjadi interaksi kuat antara obyek yang dipelajari dengan pemikiran siswa. Hal ini sesuai dengan pendapat Vygotsky menekankan bahwa dalam mengkonstruksi pengetahuanya, interaksi seseorang dengan lingkungan sangat diperlukan.

Gambar 5.4(b,c) menunjukan penjelasan konsep tentang mekanisme aliran muatan listrik dalam larutan elektrolit dan jembatan garam pada level submikroskopis. Level sub mikroskopis merupakan konsep yang membutuhkan pemikiran ditingkat molekuler atau atomik. Secara molekuler dapat digambarkan tentang aliran muatan listrik, sebagai berikut:

- Muatan listrik dapat diangkut oleh elektron atau ion

- Muatan listrik negatif diangkut oleh elektron apabila melewati penghantar logam

- Muatan listrik dalam larutan diangkut oleh ion-ion yang selalu bergerak dalam larutan

- Ion negatif membawa muatan listrik negatif, sedangkan ion positif membawa muatan listrik positif
- Ion negatif bergerak ke bagian dari larutan yang kekurangan ion negatif atau kelebihan ion positif

- Ion positif bergerak ke bagian dari larutan yang kekurangan ion positif atau kelebihan ion negatif

Melalui gambaran submikroskopis dan simbolik (rumus kimia) tersebut siswa memiliki gambaran bahwa arus listrik merupakan aliran muatan listrik, muatan listrik dalam larutan dibawa oleh ion-ion dimana ion $(+)$ bergerak dari jembatan garam ke bagian larutan yang kekurangan kation akibat reduksi (katoda). Ion (-) bergerak dari jembatan garam ke larutan yang memiliki kelebihan ion (+) akibat oksidasi (anoda). Oleh sebab itu dari media power point, siswa memiliki gambaran mikroskopis dan simbolik bahwa arus listrik dalam larutan dan jembatan garam diangkut oleh ionion.

Berdasarkan data pada tabel 2 terdapat anomali pada 2 konsep, yaitu susunan rangkaian sel volta dan aliran muatan listrik pada rangkaian dalam dimana \% mahasiswa yang menjawab benar lebih tinggi di kelas kontrol dibandingkan dengan kelas eksperimen. Jawaban benar permasalahan terkait susunan sel volta/galvani adalah "Setengah sel $\mathrm{Zn}$ dan $\mathrm{Cu}$, kawat penghantar dan jembatan garam sebagai penghubung kedua $1 / 2$ sel. Tanpa volt meter reaksi sel dapat berlangsung. Ternyata untuk kelas eksperimen menjawab "tidak dapat berlangsung" hal ini dikarenakan pada sel volta yang di demonstrasikan memiliki komponen volt-meter sebagai penunjukan tegangan yang dihasilkan.

Terkait dengan permasalahan mekanisme aliran muatan listrik/arus listrik pada rangkaian dalam maka jawaban benar adalah: Arus listrik listrik pada rangkaian dalam (larutan elektrolit dan jembatan garam) dibawa oleh ion-ion. Bagi kelas kontrol konsep tersebut dijelaskan secara narasi, sehingga mahasiswa langsung menghafal. Berbeda dengan kelas eksperimen dimana mekanisme dijelaskan secara mendalam, sehingga beberapa mahasiswa yang diduga memiliki daya nalar rendah akan terjadi akomodasi, yaitu proses pembentukan pengetahuan seseorang akibat tidak dapat mengasimilasi pengalaman barunya dengan skema/struktur yang telah dipunyai [18]. Beberapa contoh adalah pilihan siswa yang menyatakan bahwa "arus listrik listrik pada rangkaian dalam dibawa oleh elektron yang berasal dari kawat penghantar". Miskonsepsi yang terjadi pada konsep aliran muatan listrik dalam larutan elektrolit dan jembatan garam.

Dari hasil penelitian di atas menunjukan bahwa metode demonstrasi kimia yang dimodifikasi dapat meningkatkan pemahaman konsep siswa. Hal ini terkait dengan motivasi dan perhatian. Menurut Chiappetta dan Koballa [19] bahwa metode demonstrasi kimia dapat meningkatkan perhatian siswa, mendorong inklusivitas, mengembangkan konsep dan berpikir kritis, meningkatkan kemampuan observasi, menjelaskan suatu konsep dan meningkatkan kemampuan dalam mengerjakan tes hasil belajar. Menurut Deese [20] juga melaporkan bahwa metode demonstrasi dalam pembelajaran sain/kimia dapat meningkatkan motivasi 
dan perhatian siswa, mengatasi miskonsepsi, meningkatkan kedisiplinan pengajar dan menjelaskan konsep abstrak. Meyer [21] juga menyatakan bahwa dengan metode demonstrasi seorang guru dapat sebagai katalisator dalam mengkaitkan antara konsep pada pembelajaran sebelumnya dengan yang baru, sehingga siswa lebih tertaik dengan pembelajaran.

\section{KESIMPULAN}

Kesimpulan yang diperoleh dari penelitian ini adalah sebagai berikut: (1) ada pengaruh penggunaan media demonstrasi kimia yang dimodifikasi terhadap perbaikan miskonsepsi mahasiswa pada topik elektrokimia. (2) Secara kuantitatif media demonstrasi kimia mamau memperbaiki miskonsepsi sebanyak $56 \%$ mahasiswa. Hal ini disebabkan pembelajaran menggunakan media demonstrasi kimia mampu merepresentasikan 3 level ilmu kimia, yaitu makroskopis, sub mikroskopis dan simbolik

\section{DAFTAR PUSTAKA}

[1] Quilez, J. 2009. From Chemical Forces to Chemical Rates:A Historical/Philosophical Foundation for the Teaching of Chemical Equilibrium. Science \& Education, 18:1203-1251.

[2] Ozkaya, A. R. 2002. Conceptual difficulties experienced by prospective teachers in electrochemistry: Half-cell potential, cell potential, chemical, and electrochemical equilibrium in galvanic cells. Journal of Chemical Education 79: 735-738.

[3] Treagust, D. F., Chittleborough, G., \& Mamiala, T. L. (2003). The role of submicroscopic and symbolic representations in chemical explanations. International Journal of Sci-ence Education 25(11), 1353-1368.

[4] Kozma, R. B., \& Russell, J. (1997). Multimedia and understanding: Expert and novice res-ponses to different representations of che-mical phenomena. Journal of Research in Science Teaching, 34(9), 949-968.

[5] Chandrasegaran, A. L., Treagust, D. F., \& Mocerino, M. (2008). An evaluation of a teaching intervention to promote students' ability to use multiple levels of represen-tation when describing and explaining che-mical reactions. Research in Science Education, 38(2), 237-248.

[6] Muti'ah dan Sukib, 2000. Analisis Kesalahan Konsep dalam topik Konsep Mol, Stoikiometri, dan Reaksi Redoks-elektrokimia pada Matakuliah Kimia Dasar. Laporan Penelitian SPP-DPP, Lemlit Unram

[7] Muti'ah dan S.W. Al Idrus. 2007. Strategi pemecahan masalah dalam pembelajaran kooperatif untuk mengatasi kesalahan konsep siswa pada kimia dasar. Dosen Muda. Laporan Penelitian, Lemlit Unram.
[8] Chittleborough, G. D., Treagust, D. F., Mamiala, T. L., \& Mocerino, M. (2005). Students' perceptions of the role of models in the process of science and in the process of learning. Research in Science and Tech-nological Education, 23(2), 195-212.

[9] Wahyuningsih, W., Jamaluddin, J., \& Karnan, K. 2015. Penerapan pembelajaran Biologi berbasis macromedia flash dan implikasinya terhadap keterampilan metakognitif dan penguasaan konsep siswa kelas VIII SMPN 6 Mataram. Jurnal Pijar Mipa, 10(1).

[10] Armyani, I. A. P., \& Martedi, D. 2015. Pengembangan media pembelajaran audio visual program microsoft power point pada pokok bahasan organisasi kehidupan kelas VIIa SMP Negeri 19 Mataram tahun pelajaran 2012/2013. Jurnal Pijar Mipa, 10(2).

[11] Muti'ah dan Burhanuddin, 2008. Miskonsepsi mahasiswa pada topik kesetimbangan kimia. Laporan Penelitian Dosen Muda, Lemlit Unram

[12] Mutiah, Loka, I.N., dan Sukib. 2012. Pengembangan Metode Demonstrasi Untuk Meningkatkan Kualitas Pembelajaran Chemical Separation Melalui Lesson Study. Laporan Penelitian, Lemlit Unram

[13] Muti'ah, Siahaan, J., dan Sukib. 2015. Media demonstrasi kimia yang dimodifikasi untuk mengatasi miskonsepsi mahasiswa pada topic esensial kimia dasar. Laporan Penelitian HB Tahun I, Lemlit Unram

[14] Creswell, J. W. (2012). Educational research: Planning, conducting, and evaluating quantitative and qualitative research (4th ed.). Boston, MA: Pearson.

[15] Cheung, D. (2004). The scientific inadequacy of Le Châtelier's principle. Hong Kong Science Teachers' Journal, 22(1), 35-43.

[16]Fosnot, C. (1996)"Constructivism: A Psychological theory of learning". In C. Fosnot (Ed.) Constructivism: Theory, perspectives, and practice. New York: Teachers College Press.

[17]Ben-Zvi, Eylon R.B, dan Silberstein, J., 1988. Theories, Principles and Lows. Education in Chemistry. 25: $89-92$

[18] Suparno, P. (1997). Filsafat konstruktivisme dalam pendidikan. Yogyakarta: Penerbit Kanisius.

[19] Chiappetta, E.L., and T.R. Koballa. 2002. Science instruction in the middle and secondary schools. Upper Saddle River, NJ: Prentice-Hall

[20]Deese WC, Ramsey LL, Walczyk J, Eddy D (2000) Using demonstration assessments to improve learning. J Chem Educ 77:1511

[21] Meyer, L. S., Schmidt, S., Nozawa, F., Panee, D., \& Kisler, M. 2003. Using demonstrations to promote student comprehension in chemistry. J. Chem. Educ, 80(4), 431. 